\title{
各種元素に依乃鐵鋼の セメンテーンョンに就て（其七）
}

會員 理學㦨土 加濑兔

\section{結湓}

J. Laissus の研究に對して次の如き一般的結論を與へられる。

(A) 鐵合金の粉末を摭散劑として行はれるセxンテーションは次の第合によく 進行する。

（a）加熱温度の高まるこき （b ）加熱㭙間の長引くこき

（c）セメンテーションを施される铰合金の炭素量が減少するこき

（B）硬度を增加する金屬さしては

（a）セタンテーションを行つたまつの狀態に於てジルコニウム、チタン、

ウラニウム及びヴアナデウム

（b）燒入记狀態に於てウラニウム、ヂルコニシム、ヴアナヂウム、チタン 及び矹素

（C）高温度に於ける酸化作用に就いて見れば

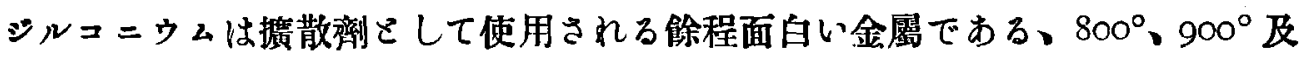
び $1000^{\circ} \mathrm{C}$ に於ける酸化率は他の總ての金屬に對して決定された數值よりも遥か に低い。即ち斯栐にして得られて援散層の保讙は酸化物の生成に對して非常に有 効であるここを示す。

クロムは同樣に良䋐果走與へる、けれごすジルコニウムに比較すれば遠く及ば ない。

（D）水に依る銹郒と云ふ立鹪からは

タンタルモクロムが甚だ興味走喚起して居る。他の總ては銹蝕に對して抵抗の 弱い搌散愿を興へる。

（E）酸に依る腐倠の見地からすれば 
（a）墟酸（50\%）に對してモりブデンは比較的耐蝕力が强い。矹素こジア ナヂウム方同樣に良結果を與へる。

(b) 硫酸 $\left(33^{\circ} \mathrm{B}\right)$ に對してタングステント大分酎蝕力がある、コバルトを 同樣に記述さるべきものである。

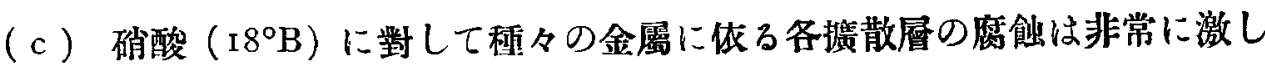
かつた、然しクロムの㙋合は全く别物の観がある、此の金屬を用ひ靯 鋼の上に得られて摭散層は硝酸 ( $\left.8^{\circ} \mathrm{B}\right)$ に侵されないと云ひ得る程度のものであ ろ。同樣に注意すべきここには、ウラニウムは非常に侵され易い擴散曆を形成す ろものであるが、他の金屬のそれに比較しては大分小さい腐蝕率を與へる。

以上の如きセメンテーションの方法を以て金屬を被㠅するここは單なる電氣鍍 金法に優る點、站に多くの興味ある問題を與へて居るものと思はれる。劣ほ單な

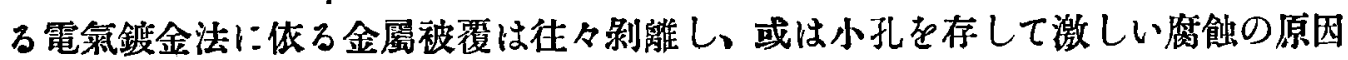
こなる等の缺陷ある故、之を救濟するにセメンテーションに於て行はれたと類似 の熱處理を施せば宜しい、即ち例へば軟鋼片を先づ電解的にクロムで被覆し、次 にI $100^{\circ}$ - I $200^{\circ} \mathrm{C} に$ 於て 5-10時間加熱するときは、クロムは基質中に擴散し、 セタンテーションを行つたを類似の表面を璵へやう。

最後にJ. Laissus の得られて結果を綜合して第I4表 (a)、（b）、（c）は興味ある ものである。

第 I4 表 各試羷片の諸性買の比較 (a)

\begin{tabular}{|c|c|c|c|c|c|c|c|c|c|c|}
\hline \multirow{4}{*}{$\begin{array}{l}\text { セメンテーショ } \\
\text { ンの種類及び試 } \\
\text { 驗した鋼 }\end{array}$} & \multicolumn{7}{|c|}{ 硬 } & \multicolumn{3}{|l|}{ 度 } \\
\hline & \multicolumn{5}{|c|}{ セメンテーションね行つけ滥のもの } & \multicolumn{5}{|c|}{$875^{\circ} \mathrm{C}$ 加水烍入んした：日の } \\
\hline & \multirow{2}{*}{$\begin{array}{r}\text { 等級 } \\
\text { (3) }\end{array}$} & \multirow{2}{*}{$\begin{array}{l}\text { ショーフ } \\
\text { 硬 度 }\end{array}$} & \multirow{2}{*}{$\begin{array}{l}\text { ロツク } \\
\text { ウル } \\
\text { 硬 度 }\end{array}$} & \multirow{2}{*}{\multicolumn{2}{|c|}{ 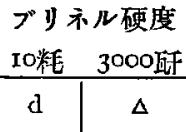 }} & \multirow[t]{2}{*}{ 等級 } & \multirow{2}{*}{$\begin{array}{l}\text { ショー7 } \\
\text { 硬 度 }\end{array}$} & $\begin{array}{l}\text { ロック } \\
\text { ウエル }\end{array}$ & \multicolumn{2}{|c|}{$\begin{array}{l}\text { ブリネル硬度 } \\
\text { I0粍 3000瓦 }\end{array}$} \\
\hline & & & & & & & & 硬 度 & d & $\Delta$ \\
\hline 硬 蜼( $(0.80 \% \mathrm{C})$ & $\mathbf{I}$ & $35-40$ & $\mathrm{C}-27$ & 3.96 & 236 & $\mathbf{I}$ & $80-85$ & $c-65$ & $2.4{ }^{\circ}$ & 653 \\
\hline$\because ル コ ニ ウ ム ~$ & 2 & $30-35$ & $C-26$ & 4.00 & 229 & 3 & $75-80$ & $C-58$ & 2.63 & 542 \\
\hline 及 & 3 & $30-35$ & $\mathrm{C}-24$ & 4.10 & 217 & 6 & $60-65$ & $\mathrm{C}-50$ & 2.90 & 444 \\
\hline ウ $ラ=ウ ム$ & 4 & $30-35$ & $\mathrm{C}-23$ & 4. 5 & 212 & 2 & $80-85$ & $C-64$ & 2.45 & 627 \\
\hline
\end{tabular}




\begin{tabular}{|c|c|c|c|c|c|c|c|c|c|c|}
\hline 牛硬銅 $(0.35 \%$ C) & 5 & $30-35$ & $\mathrm{C}-22$ & 4.20 & 207 & 5 & $70-75$ & $C-54$ & 2.76 & 495 \\
\hline ヴアナデゥム & 6 & $15-20$ & $B-87$ & 4.57 & $17 \mathrm{I}$ & 4 & $70-75$ & $C-56$ & $2.7^{\circ}$ & 514 \\
\hline 㱚 & 7 & 15 & $B-74$ & 5. 10 & 137 & 6 & $60-65$ & $C-50$ & 2.90 & 444 \\
\hline $\begin{array}{lll}3 & 0\end{array}$ & 8 & - & $B-73$ & 5.15 & 134 & 8 & $40-45$ & $C-38$ & $3 \cdot 45$ & 311 \\
\hline 軟 鋼 $(0.15 \%$ C) & 9 & 一 & $\mathrm{B}-7 \mathrm{O}$ & 5.25 & 128 & 8 & - & - & - & - \\
\hline モ. リ ブデン & Io & - & $B-67$ & 5.40 & $12 \mathrm{I}$ & I I & $20-25$ & $C-15$ & 4.50 & 179 \\
\hline タングステン & I I & - & $B-65$ & 5.50 & I16 & I 2 & $20-25$ & $c-9$ & 4.80 & $18 x$ \\
\hline$=ハ ゙ \quad ル$ & 12 & - & $B-64$ & 5.55 & $\mathrm{I}_{4}$ & 9 & $40-45$ & $\mathrm{C}-37$ & 3.50 & 302 \\
\hline $3=3 N$ & 13 & - & $B-62$ & 5.65 & 109 & 10 & $20-25$ & $c-16$ & 4.45 & 183 \\
\hline
\end{tabular}

表 中

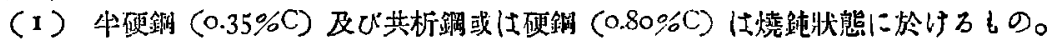

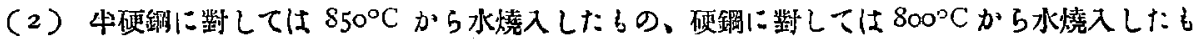
D。

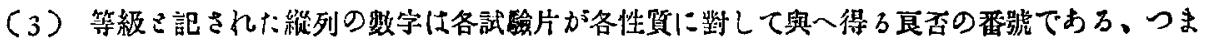
り No. 1 は其の邊の性質に就て最冝であり、No. 2，3，4：次第に劣乃：きた示す。

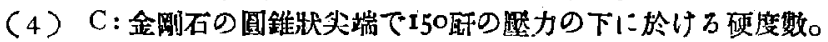

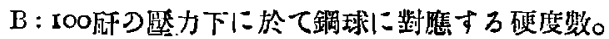

( $\mathrm{b}$ )

\begin{tabular}{|c|c|c|c|c|c|c|}
\hline \multirow{3}{*}{$\begin{array}{l}\text { セメンテーション } \\
\text { の種類及び訊騟し } \\
\text { た鎆 }\end{array}$} & \multicolumn{4}{|c|}{ 酸 } & \multicolumn{2}{|l|}{ 化 } \\
\hline & \multicolumn{2}{|c|}{$800^{\circ} \mathrm{C}$-30時間 } & \multicolumn{2}{|c|}{$9^{\circ} \mathrm{OoC}-3$ 時間 } & \multicolumn{2}{|c|}{$1000^{\circ} \mathrm{C}$-30時間 } \\
\hline & 等級 & $\begin{array}{c}\text { 酸 化 率 } \\
\alpha\end{array}$ & 等櫂 & 酸 化 率 & 等級 & 酸 化 率 \\
\hline 硬 鋼 $(0.80)$ & $"$ & " & $"$ & $" 1$ & $"$ & $" 1$ \\
\hline$\forall ル コ=ウ ム$ & I & 2.2 & $\mathbf{I}$ & 6.6 & I & I9.8 \\
\hline$\neq \quad \not$ & 3 & 17.8 & 4 & $89 \cdot 3$ & 3 & 155.4 \\
\hline ウ $\bar{\nearrow}=$ ウ & 5 & 29.3 & 10 & 132.5 & 8 & 229.9 \\
\hline 牛 硬 銅 (0.35) & $"$ & $" 1$ & $"$ & " & $" 1$ & i) \\
\hline ザアヂウム & 6 & $3^{6.2}$ & II & 160.8 & Io & $\mathbf{z 3 9 . 0}$ \\
\hline 硼 & 4 & 18.3 & 9 & 127.7 & I I & 287.9 \\
\hline$\eta$ & 2 & 17.6 & 2 & 38.6 & 2 & 144.4 \\
\hline 軟 鋼 (0.15) & I I & 4.6 & 3 & 88.6 & 5 & 179.9 \\
\hline モリプ デン & 9 & 41.2 & 7 & 116.2 & 9 & 233.2 \\
\hline ダン゙ステン & 10 & 43.0 & 5 & 110.0 & 7 & 224.2 \\
\hline$=$ バ $ル 1$ & 7 & 38.5 & 6 & 110.4 & 4 & 167.8 \\
\hline$B=3 ル$ & 8 & 39.9 & 8 & 119.5 & 6 & 183.5 \\
\hline
\end{tabular}


( c )

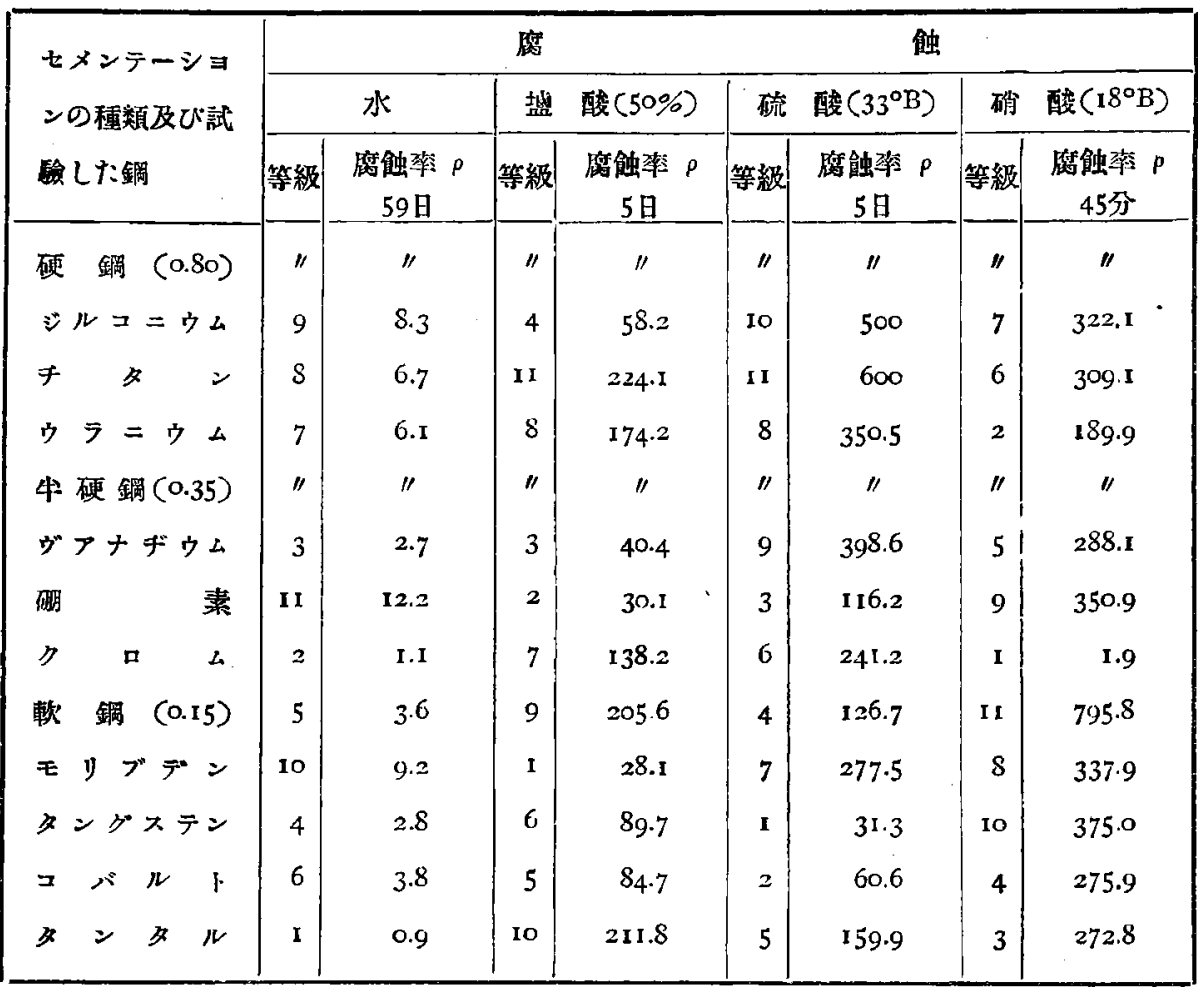

\section{補遺 アルミニウムに依るセメンテーション}

これにはJean Cournot (1) の研究がある。從桃金屬をアルミニウムで被嘚する 方法としては色々知られて居る、即ち純アルミニウム又はアルミニウム合金の浴 中に浸漬する方法、電鍍法、壚化アルミニウム $\left(\mathrm{AlCl}_{3}\right)$ 蒸氣の作用に依る力法。

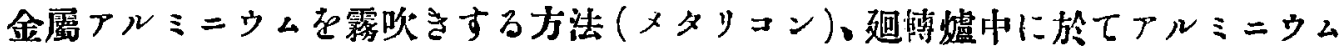
一アルミナ一笽化アンモニウムと處理する方法等があるが、粉末狀のアルミニウ ム鐵 (約 $\mathrm{Al}_{3} \mathrm{Fe} に$ に相當する組成のもの)でセヌンテーションを行ふのが最も迅速 で且つ最る一樣な結果を與へろここが解つた。

$70 \times 12 \times 3$ 粍の試驗片をアルミニウム鐵及び約 $0.5 \%$ 罝化アンモニウムと共に

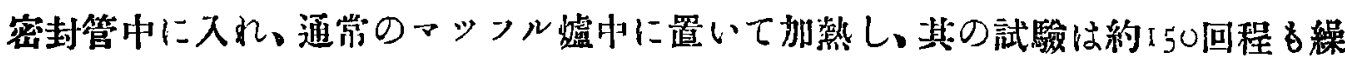
返されて。

(1) Jean Cournot: Compt. rend., 182 (1926), 696; Rev. da Met., 23 (I926), 219. 
られた試驗片の顯微鏡組織を檢查し、又酸化性の大氮の通つてるマッフル中 に放て $1000^{\circ} \mathrm{C}$ に加熱し、酸化に對する抵抗力を試驗して、而して其の銹ついた 點が現はれるに要した時間を注意し、邓それ等の試驗結果を㙷微鏡的に照查した。 試驗の大部分は炭素量の少ない軟鋼で行はれて。第38圖に示す $\mathrm{Fe}-\mathrm{Al}$ 系の狀 態圆に依れば、固溶體の區域が二つある、即ち其の一つはアルミニウム側の化合 物 $\mathrm{Al}_{3} \mathrm{Fe}$ より成るもので、他の一つは鐵側の $65-100 \% \mathrm{Fe}$ を含むるのである。

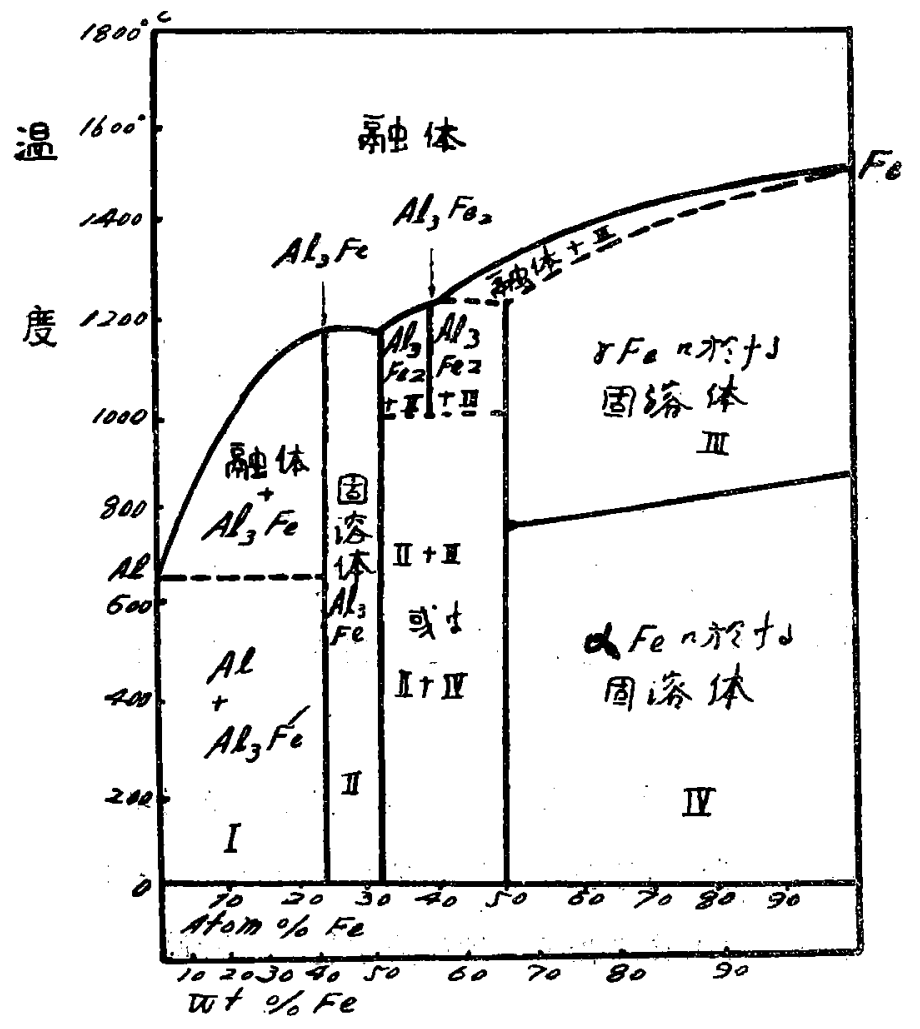

第38周 $F_{0}-A l$ 系狀態图 (Kum akow. Urasow RGorigojiew)
Nol撗散の結果、明膫に 分れた二つの固溶體 の層が試醶片の表面 に生成する。外部の 層は $\mathrm{A}_{l_{3}} \mathrm{Fe}$ の固溶體 で通常薄く（厚さO.I 粍以下)、多孔質で脆 弱、且つ不規則であ る。

內部の曆は處理が旨 く行はれて簀合には 一樣な厚さを有す、 抵抗力の强い不透明 な層である。後で加 熱すれば外部の層は 膨れ上り、一層多孔 算にな.5.内部の層

に多少吸收されてから迅速に崩壤する、同時に內部の層は肉方に摭政して地鐵の

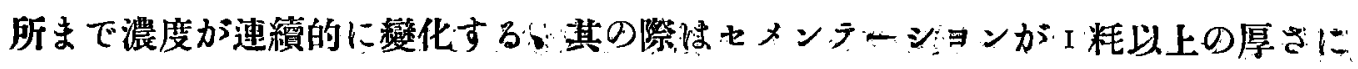
達して居るのである。 


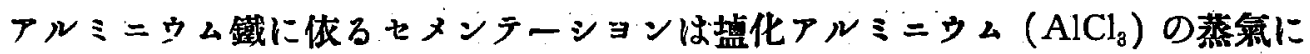

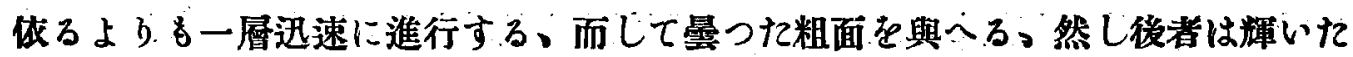
滑面它與へる。

擴散層の厚さ訬處理の時間と共に增加し、割合は温度の上昇と共に增加する。 温度 $850^{\circ} \mathrm{C}$ に於てすらも認むべき程のセタシラーションがあるけれども、速度は

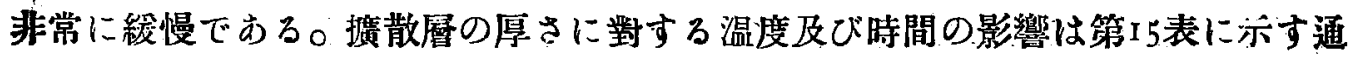
りである。

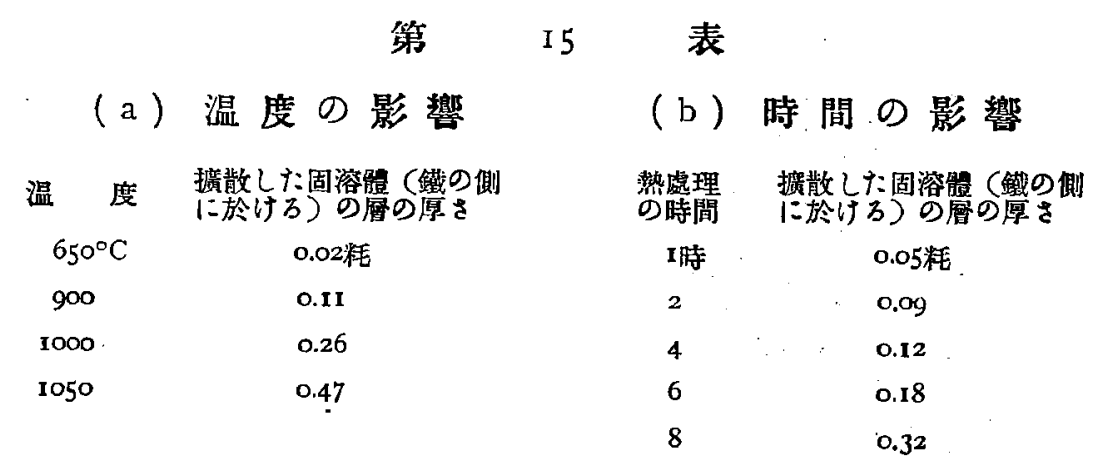

酸化に對する抵抗力は摭散されて暜の厚さに關倸する、而して處理したるのと しないるのとの美異は、低温度のときよりす高温度のときの方が著しい、それ故 此の處理は $1100^{\circ} \mathrm{C}$ 以上の温度に置かれる金屬に對しては利笽むるすのとは考へ られない。

硬鋼は軟鋼よりもセタンテーションを行ふに多くの時間を要し、灰銑鐵は更に 然りとす、アルミニシム走援散しれ層性可鍛性がない体つてセタンテーション

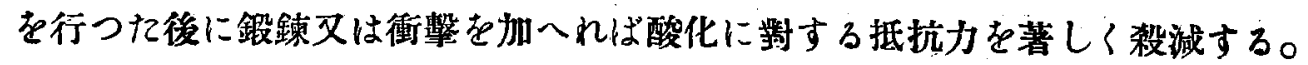

\section{顯微鏡組 織}

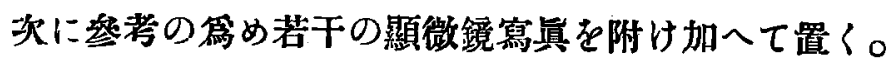
腐蝕液A $\cdots 4 \%$ ビクリン酸のアルコール溶液で腐蝕したすの。 腐飿液 $\mathrm{B} \cdots 4 \%$ 硝酸のアルコール溶液で腐蝕したもの。 


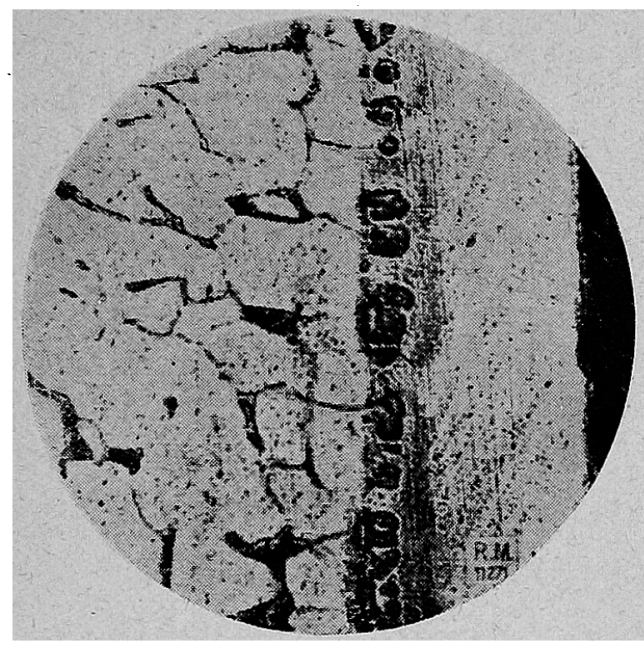

(1) $0.15 \%$ 岸素䤡 $1000^{\circ} \mathrm{C}$ で 2 時間的素九船散したしの。 $\times 200$ 鹰触腹 $\mathrm{B}$.

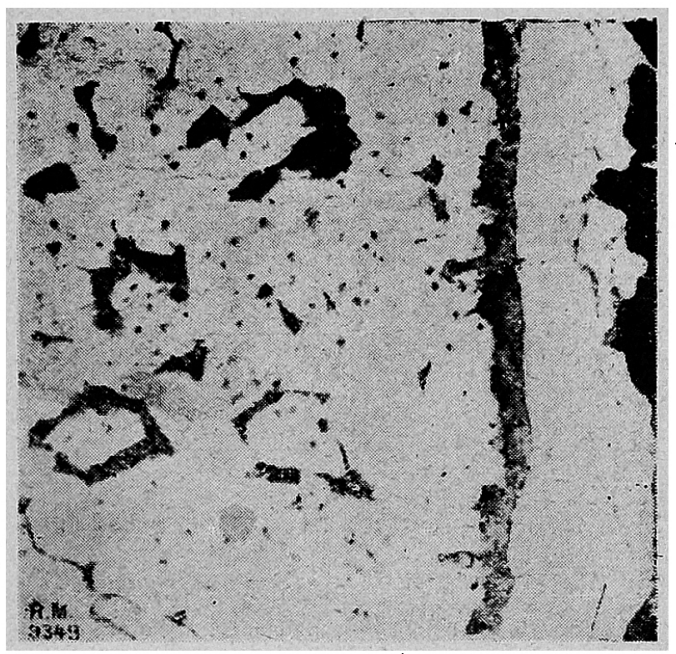

(2) $0.15 \%$ 炭素鋼 $1=1100^{\circ} \mathrm{C}$ で10時間ク口ムわ摭散したいの、

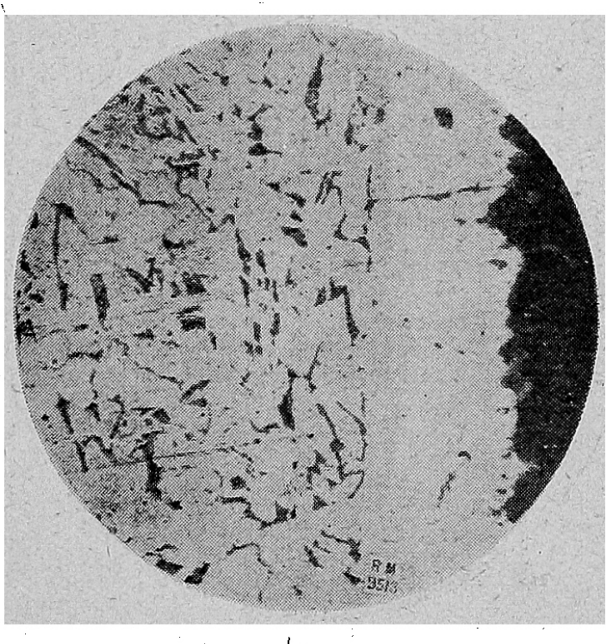

(4) $0.15 \%$ 宸素踻1: $1100^{\circ} \mathrm{C}$

で5時間タシグステンか散散し †:6の、 $\times 100$ 鹰触液 B. $\times 200$ 触液 $\mathrm{A}$.
(3) 電解鐵に1200ำで10㭙

間》口，公摭散した6の。

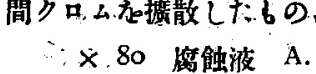

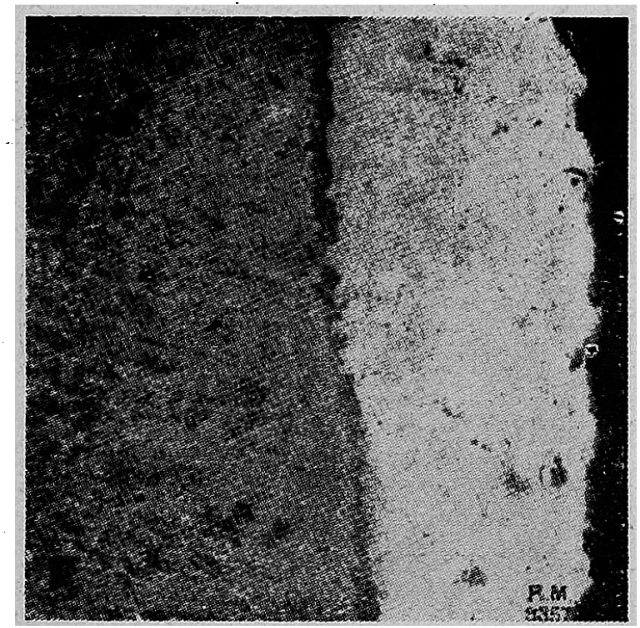




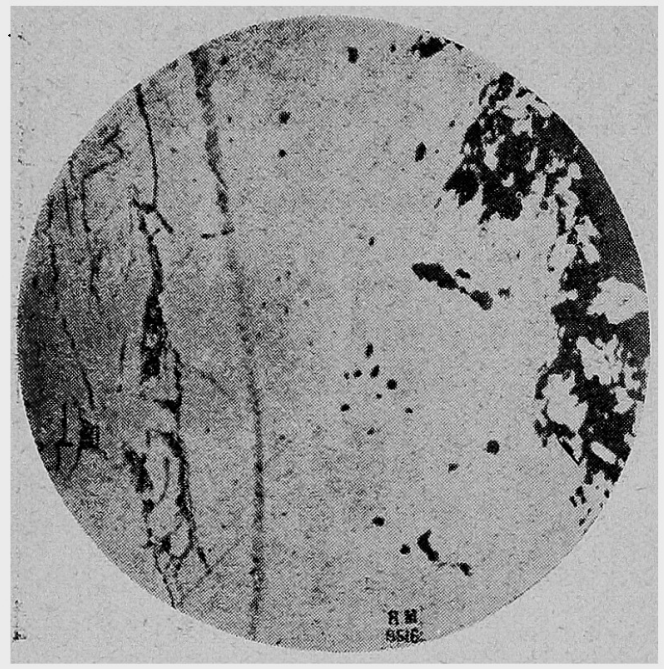

(5) 電解鐵に

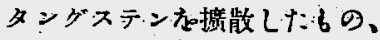
$\times 200$ 腐玲液 $B$.

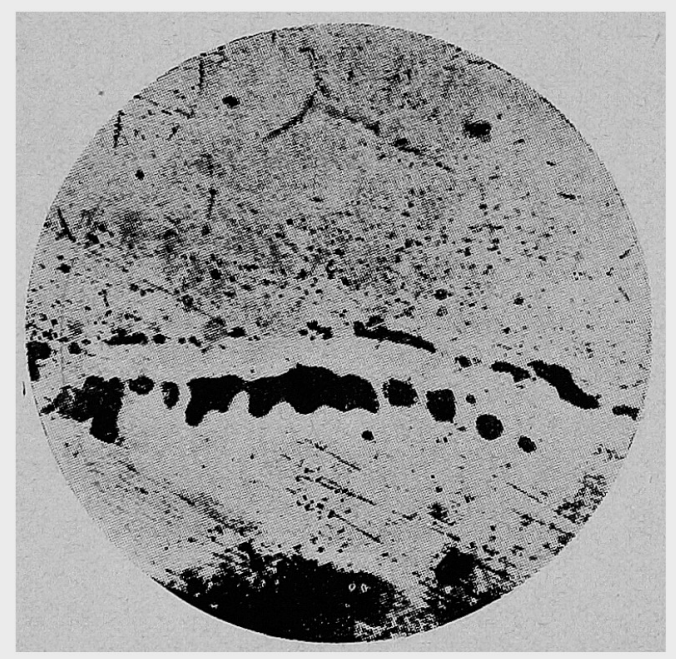

(7) $0.15 \%$ 炭素鋼に $1200^{\circ} \mathrm{C}$

で1時間モりブデンた㨨散した

6の、 $\times 200$ 腐触液 B:

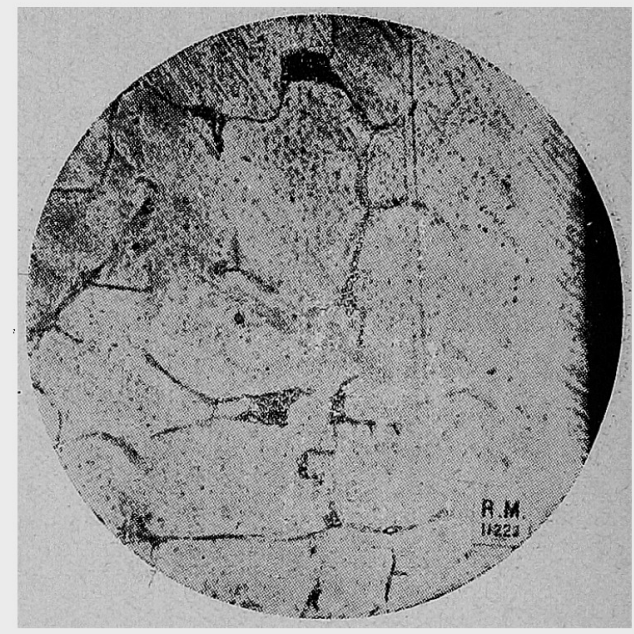

(6) $0.15 \%$ 岸素鋼に $1000^{\circ} \mathrm{C}$.

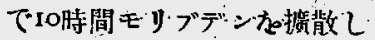
たしの、メ200 腐強液 B.

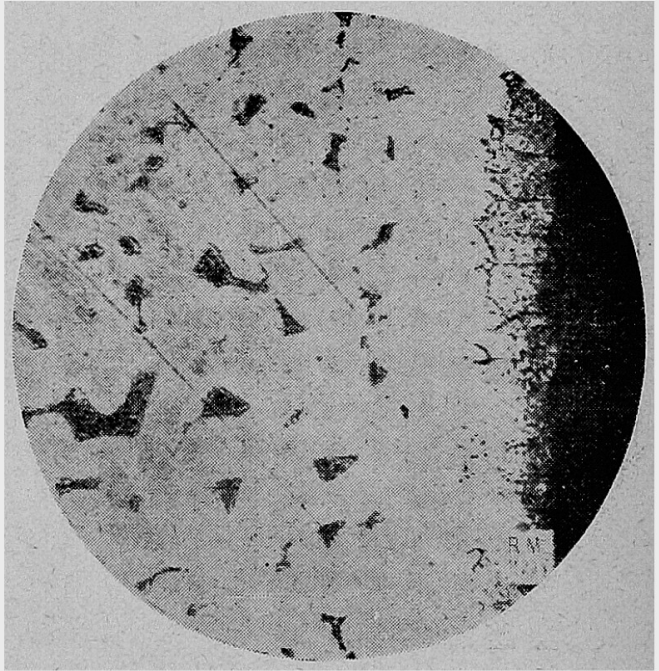

(8) $0.15 \%$ 宸素銅1 $1=900^{\circ} \mathrm{C}$

で 5 時間タンタ心な拨散した

にの. × 200 腐強液 A. 


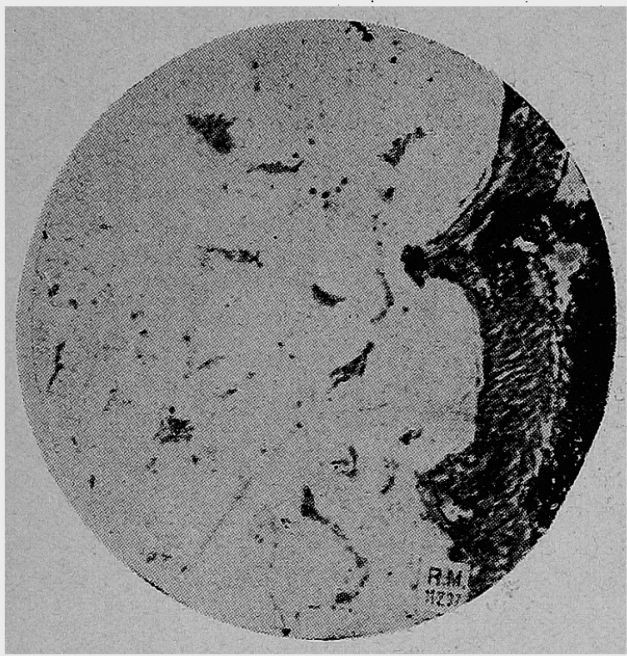

(9) $0.15 \%$ 宸素鋼 $1=1100^{\circ} \mathrm{C}$ で時間タンタルれ據散した： の、 $\times 200$ 腐蝕液 $\bar{A}$.

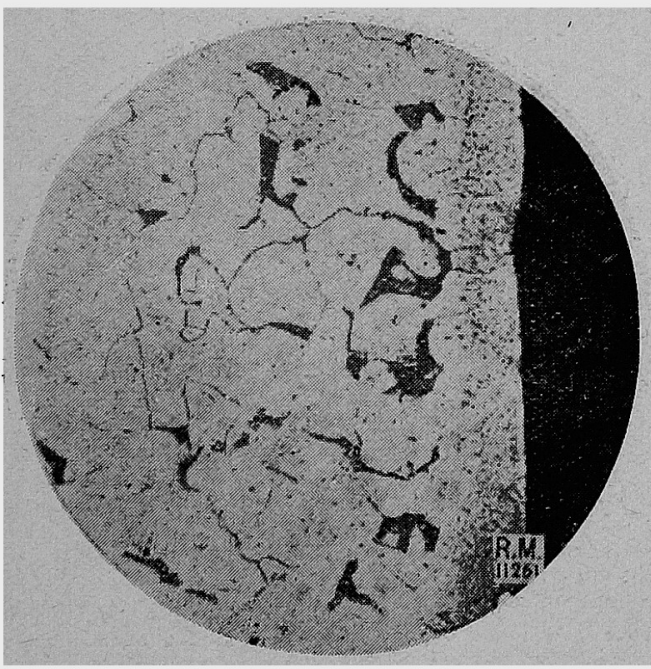

(II) $0.15 \%$ 炭素鋼に $1000^{\circ} \mathrm{C}$

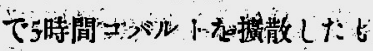

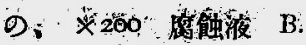

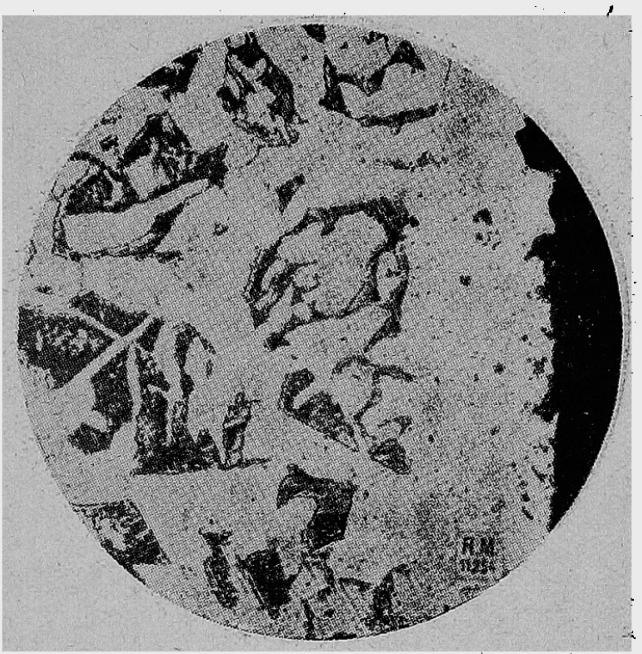

(10) $0.15 \%$ 炭素政1 $1200^{\circ} \mathrm{C}$

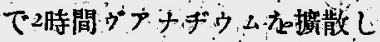

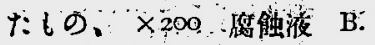

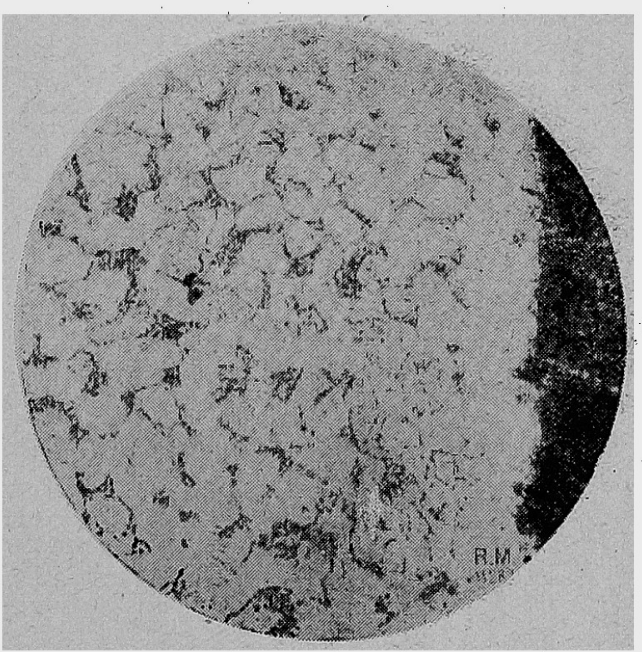

(12) $0.15 \%$ 崖素鋼に $10000^{\circ} \mathrm{C}$

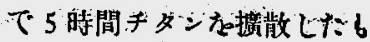

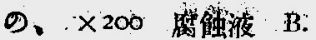




\section{IIO.}

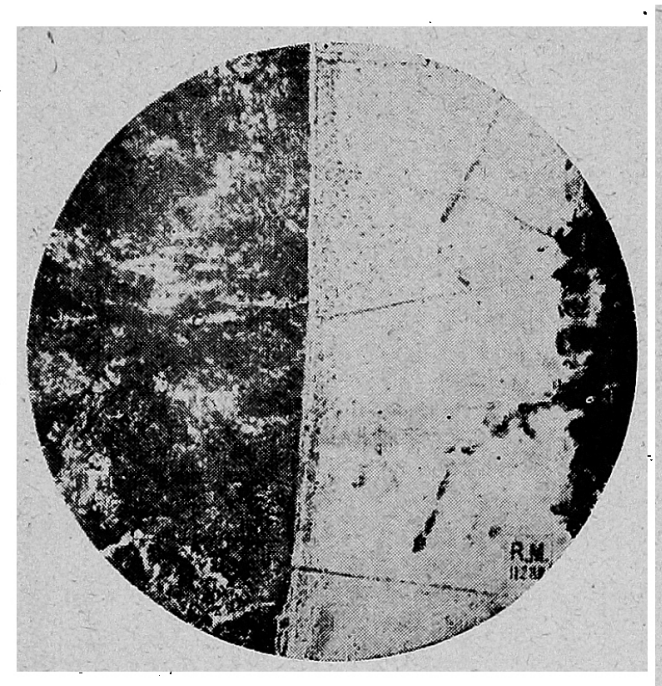

(13) $0.15 \%$ 炭素銅に $1100^{\circ} \mathrm{C}$

で 5 時間テタンな撗散したも

פ、 $\times 200$ 鹤触㳸 $\mathrm{B}$.

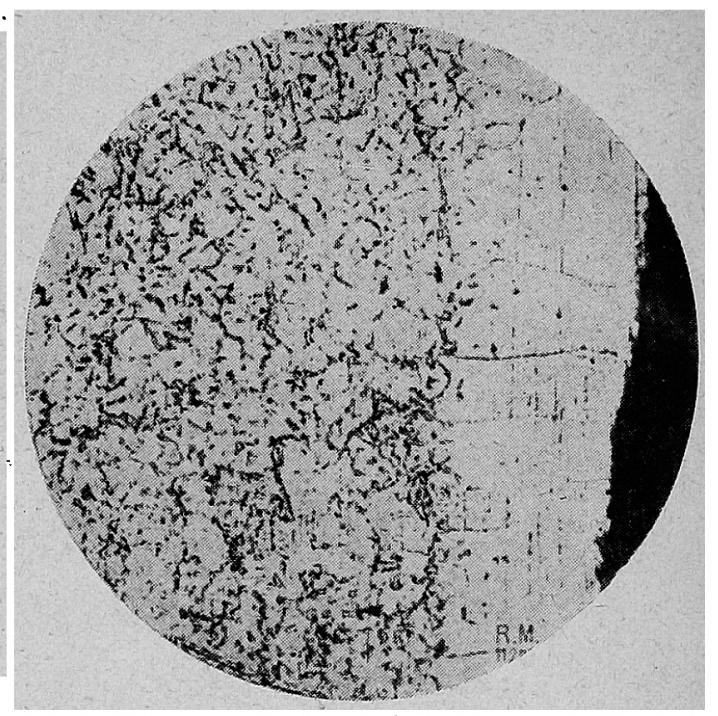

（14）電解鐵に $1500^{\circ} \mathrm{C}$ で5時。

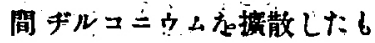

9、 $\times 200$ 得触被 B.

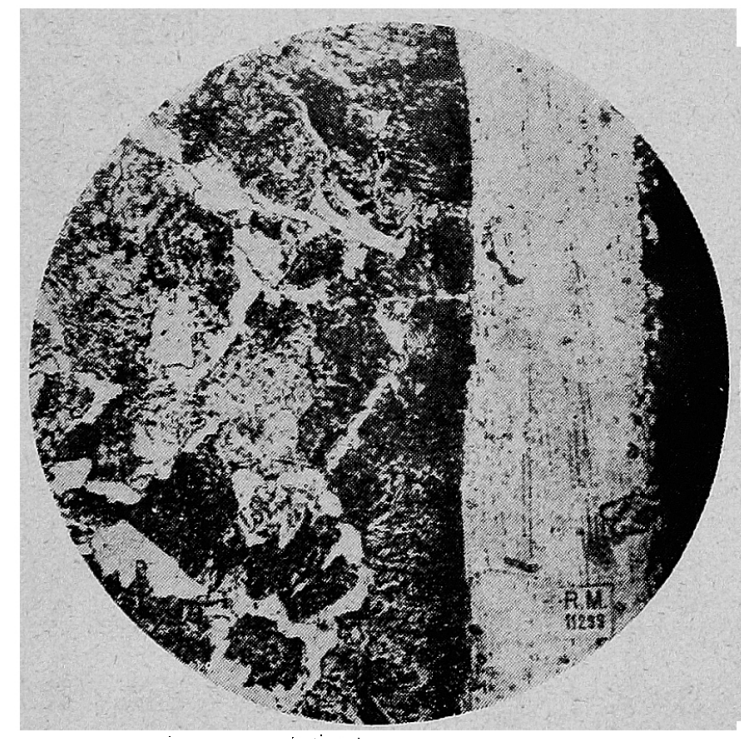

(15) $0.15 \%$ 炭素鋼: $=1100^{\circ} \mathrm{C}$

で 5 時間ギルコ三ウムれ摭散 した 6の、×200腐触液 B.

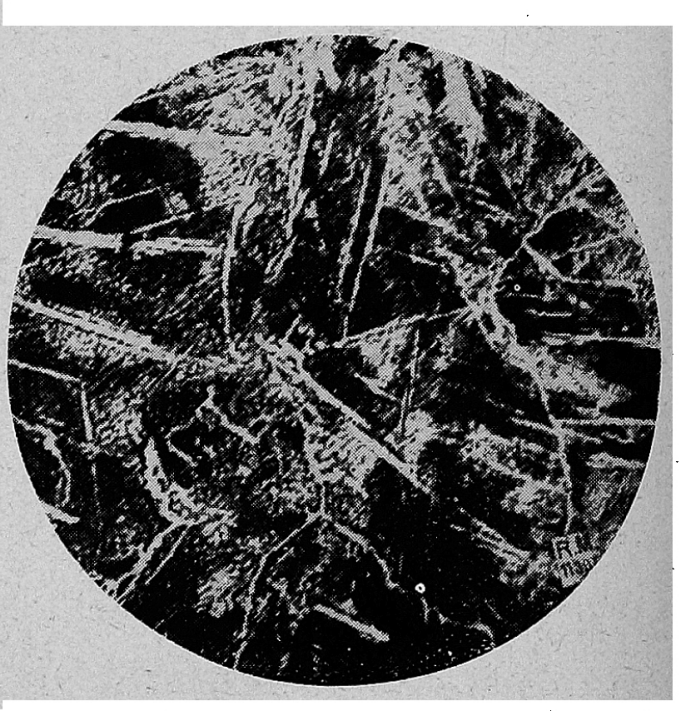

(16) $0.15 \%$ 宸素剑1: $1100 \% \mathrm{C}$

で5時間ウ.ラニウム长鶢散した 6の; $\times 200$ 屈玲埌 $\mathrm{B}$. 